This is an Accepted Manuscript of an article published by Taylor \& Francis Group in Public Management Review on 1 Jun 2019, available online:

http://www.tandfonline.com/10.1080/14719037.2019.1630134.

Enacted discretion: policy implementation, local government reform and education services in Pakistan

Seemab Farooqi \& Tom Forbes

Stirling Management School

University of Stirling

Stirling

United Kingdom 


\title{
Enacted discretion: policy implementation, local government reform and education services in Pakistan
}

\begin{abstract}
This article examines policy implementation in the Pakistan education sector introduced by the Musharraf local government reforms between 2001 and 2009. By devolving administrative and financial powers from the provincial to local government, the reforms sought to address weaknesses in existing local government provision. Our analysis developed a process model of policy implementation that suggests that while extensive structural decentralisation did occur, in practice this was more limited leading to what we term enacted management discretion, where local managers overcame weak organisational capacity, resource constraints and increased bureaucratic control from higher tiers of provincial government to manage and deliver educational services.
\end{abstract}

Key words: policy implementation, managerial discretion, Local government reform, Pakistan 


\section{Enacted discretion: policy implementation, local government reform and education services in Pakistan}

\section{Introduction}

Decentralisation has become an important driver of local government reform in recent years with several policy initiatives that have seen changed structures, funding and accountability mechanisms (Kwon 2013). A key part of Pakistan's 2001 local government reforms focussed on decentralisation and was based on an acknowledgement that in order to provide efficient services, a bottom up approach to restructuring was needed (National Reconstruction Bureau 2000). The reforms were also unusual in that they were introduced by the Musharraf military government to promote non-political local democracy. Unlike attempts at decentralization in other countries that have been motivated by changes in state ideology or other forms of multilateral pressure, in Pakistan, the military's need for legitimization of state control was the prime reason behind local government reform (Cheema, Khwaja, and Qadir 2006). The reform policy also aimed to address weaknesses in existing local government by introducing extensive decentralization and electoral reforms intended to create local ownership of institutions by the devolution of political, administrative and financial decision making to local government (Government of Pakistan 2000; Manning et al. 2003; Kardar 2006). In this paper, we examine the role of managerial discretion in the implementation of local government reform.

Studies of policy implementation have a rich history. Early work emphasised a top down approach with policy designed centrally and implemented automatically at lower levels emphasising implementation factors that were controlled by the centre (Van Meter and Van Horn 1975; Matland, 1995). Bottom up approaches emerged in 
the early 1980s as a criticism of the top down framework arguing that this was too simplistic and did not account for policy failure. The bottom up approach suggested it is more realistic to consider policy implementation from the perspective of local communities and in particular front line service providers or street level bureaucrats (SLBs) such as teachers or social workers who, due to ambiguous policy goals, use a degree of discretion in how they implemented policy (Lipsky, 1980, 2010; Hull and Hjen, 1987). In both approaches the role of managers is largely overlooked. Top down perspectives perceive managers as conduits for policy reform rather than having a direct role in its implementation. In bottom up perspectives, the role of managers are limited to gaining SLB compliance and who do not pursue their own agendas although in his later work Lipsky (2010) acknowledges that managers can empower policy implementation. However, we argue that managers act as SLBs in their own right and are also able to use discretion in the implementation of policy. To test our ideas, we use the context of local government reform in Pakistan. Our research question was to what extent were local managers able to exercise newly acquired powers of decision making? In answering this question, we develop a three-stage process model which suggests that while decentralisation did transfer powers to local levels, in practice discretion was limited due to constraints placed on managers from institutional pressures and actors at higher levels who were intent on holding onto power based on former provincial arrangements. To overcome these constraints mangers engaged in what we term enacted discretion where they were able to overcome some constraints in decision making by using discretion based on micro-practices underpinned through individual, organisational and contextual factors. Having set out the context of the paper, its structure is as follows. In the next section, we provide an overview of the policy implementation literature highlighting the factors that influence the policy-making- 
implementation continuum. We then outline the context of our study and the local government reform agenda in Pakistan. Finally, we describe our methodology and data analysis approaches before presenting our findings, discussion and conclusion.

\section{Policy Implementation}

Until the 1980s, studies of policy implementation were dominated by a top down perspective (O'Toole 2000; Sabatier 1991) which examined factors that contributed to reform failures (Cloutier et al. 2016; DeLeon and Linda 2002; Sabatier 1986). These included poor policy design, poor planning, and a lack of communication (May and Winter 2009). During the 1980s a new wave of analytical frameworks provided a 'bottom up' approach to policy implementation (Lipsky 1980) highlighting the pivotal role of SLBs who used discretion in delivering services to the public.

Lipsky’s seminal work provided a framework that linked policy, organisational structure, resources, and SLB perceptions of policies. The central tenant of Lipsky's framework (1980; p. xii) is that 'the decision of street level bureaucrats, the routines they establish and the devices they invent to cope with uncertainties and work pressures, effectively become the public policies they carry out' and that public policies are best understood in 'the crowded offices and daily encounters of street level workers' (Op.Cit). Lipsky characterised 'discretion' as a relative term making a distinction between 'policy as written' and 'policy as performed' (p.xvii). This underlies a paradox as SLBs were both required to be responsive to local needs while at the same time were constrained in their discretion of who received services

This paradox continued in subsequent SLB literature. Brodkin (2011b) suggests that discretion involves more than just responding to incentives or preferences. Discretionary choices are driven from specific organisational conditions that interact 
with performance incentives to create a street level calculus of choice. Stensöta (2012) argues that frontline workers' discretion provides them with the latitude to interpret rules in the implementation process, and hence they become the 'defacto bureaucratic policy makers' when implementing programs. It is worth noting that the term discretion is used in several ways in the SLB literature with a distinction made between discretion as 'degree of freedom as prescriptively granted by rule maker to an actor (discretion as granted') and discretion as 'actually being used' (Hupe 2013, pp. 434-435). Thus for Evetts (2002), discretion is freedom within constraints, while Tummers and Bekkers (2014, p. 530) discuss 'discretion as experienced' arguing that there is a positive relationship between discretion and a willingness to implement policies.

Managers are located at an intermediary level between political elites who formulate policy and SLBs who practice policy at the service delivery level. Nevertheless, the implementation work of managers' work at the service delivery level is not given due consideration in Lipsky' SLB perspective with managers seen as simply striving to gain SLB's compliance rather than pursuing their own agendas. This omission ignores managers as SLBs in their own right who can also use discretion to influence the policy implementation process (Evans, 2015). An under explored area (Matland, 1995), recent studies are beginning to examine the role of managers in policy implementation. Soss et al (2011) in a study of welfare managers in Florida, examined managers discretion and found that despite pressures to conform to policy mandates, managers had broad discretion in that they were authorised to make a wide variety of decisions affecting the public. Such discretion was ineradicable, in the sense that they could always find ways to push a decision in a direction they preferred despite the performance pressures they faced. 
The policy literature also highlights the role of organisational forces in shaping implementation. While explaining how such forces impinge on SLBs delivering frontlines services, there are similar implications for managers. Organisational forces include structures and processes (Lipsky 2010), the role of individual agency (Keiser and Soss 1998; Tummers, Bekkers and Steijn 2012), the personal characteristics of SLBs (Keiser 2010; Brodkin 2011) and macro and meso contextual influences (Hupe and Buffat 2014; Rice 2003) which can limit discretion. Common themes from this literature suggests four explanations of understanding key influences on implementation practices. Firstly, the policy design and resources devoted to policy execution (Van Meter and Van Horn 1975; Hill 2003) assumes that policy meanings are widely shared at the implementation level. In practice policy contains ambiguous if not conflicting goals with implementation decisions constrained by the interpretation of policy. Policies should also be accompanied by sufficient resources to enable organisations to do what they are expected to do (Brodkin 2011b). Capability issues such as poorly trained staff or the inadequacy of financial and human resources, often result in poor implementation of reforms (Hupe and Buffat 2014). The characteristics of the implementing organisations provide imperatives that can shape what happens at the service delivery level (Van Meter and Van Horn, 1975, Sandfort 2000) which can include formal structures and processes (Hill 2003; Hill and Hupe 2008; Wellstead and Stedman 2010). There is also a recognition that the economic, political and social environment of the implementing agency affects not only the characteristics of implementing organisations but also their dispositions for change (Berman 1978). In particular, stakeholders at various institutional levels - politicians, bureaucrats in other agencies, and the managers of SLBs provide signals regarding the content and importance of policy which in turn can influence attitudes toward policy and its implementation (Keiser 2010; Keiser and 
Soss 1998; Stensöta 2011). Managerial influences are particularly important as key communicators of policies and expectations to SLBs. As decision-making authority is delegated, this consequently affects SLB levels of discretion (Hill 2006; Riccucci et al. 2004). Finally, the role of personal values and attitudes towards policy issues and the interpretation of policies in relation to personal beliefs has been recognised as important in policy implementation (Goel 2014; Hupe and Buffat 2014; Meier 1993; Piore 2011). Maynard- Moody and Musheno (2003) argue that implementation actions are shaped by personal beliefs about what is fair or unfair and what publics are worthy or unworthy. In particular, the knowledge of policies and their interpretation play a significant role in implementation (Hill 2003; May and Winter 2009; Sandfort 2000) affecting decisions at the implementation level which has been referred to as 'policy alienation' (Tummers 2013).

In sum, managerial discretion is an important topic in public management because it relates to the achievement of policy objectives including good governance, effectiveness in service delivery, and citizen satisfaction. Further, because discretion is often the conduit through which such objectives are attained, we argue that greater attention is required to understand the characteristics and consequences of managerial discretion. However, the focus of much research has been at the top level much to the exclusion of managers located at lower levels, for example as found in local government, but who nevertheless, carry out work that is fundamental to policy implementation. This article thus aims to examine:

1) the conditions under which managerial discretion is exercised, and the relative importance of factors that may influence discretionary outcomes and

2) how influences on managerial discretion impact successful implementation of policy reforms. 
In doing so, we use Lipsky's framework as it provides a bottom up approach to examine managers' discretion who are street level bureaucrat in their own right. Although, Lipsky's key focus was on structural and contextual conditions and their impact on SLB's discretion, we have adopt a more holistic approach and integrate structural and informal practices on shaping managers' discretion as outlined in our process model of enacted discretion.

\section{Pakistan Local government and education reforms}

Following independence in 1947, Pakistan became a federal state consisting of four provinces; Punjab, Sindh, Khyber Pakhtunkhwa and Baluchistan which were divided into three administrative levels: Divisions, Districts and Tehsils. A number of factors led to weak local government (Jalal 1995). Legitimacy was established by localized patronage acting as a conduit between local level constituencies and a nonrepresentative center. Governance was centralized and decisions regarding planning and development were not taken by local bodies which lacked legitimacy and responsiveness to local priorities with no incentives for high quality service delivery. These weaknesses resulted in a military coup in 1958 and the first of a series of military governments which centralized political power by the dissolution of elected provincial assemblies and the introduction of a presidential constitution which sought to preserve a non-representative institutional role at the centre (Paracha 2003). Political power was centralized by the disqualification of political parties distorting electoral competition with the military governments requiring local government elections to be held on a nonparty basis. Following the re-establishment of a civilian government and a return of political parties, local government structures from the military regimes were either suspended or abolished (Wilder 1999; Keefer, Marayan, and Vishwanath 2003). 
The most recent reforms were initiated by the military government of General Pervez Musharraf in 2001 as part of a broader reform strategy linked to his main agenda of "reconstructing the institutions of the state" and establishing representative local government (Manning et al. 2003, p.1). The reforms emphasized citizen participation in the planning, development and oversight of service delivery. A national reconstruction Bureau (NRB) was charged with improving the organisation of local government (Government of Pakistan 2000). Under the new arrangements, the provincial government would be responsible for policy making, the regulation of the social sectors, and setting performance standards. Financial resources and the administration of services would be transferred to local government. Critical to the reform policy was increased managerial discretion offered to local level managers in the delivery and management of education services. Figure 1 provides an overview of the local government reforms.

\section{[Insert figure 1 here]}

Under the reforms public services underwent a series of changes accompanied by devolution of administrative and financial control to the local government level. We examine education services which became aligned with existing national policies of decentralizing which transferred primary, secondary and college education services from provincial education departments to district authorities (local government). Provinces would now determine education policy with local government implementing policy. New levels of management were created at three levels: executive district officers (EDOs), district education officers (DEOs) and deputy district education officers (DDEOs). Table 1 outlines their delegated powers under the reforms. 
The main element of the education reforms included (Ministry of Education 2002):

- Devolving administrative and financial autonomy to education Departments

- Increasing client involvement in service provision though constituting School Councils (SCs) to be responsible for the management of schools

- $\quad$ Encouraging third sector/NGO or private sector participation in service delivery through a flagship programme called the 'Adopt A School initiative' (AAS) which would provide additional resources for schools and improve the education quality of failing or low performing schools.

\section{Methodology}

We utilised a qualitative methodology based on semi-structured interviews with managers based in the education departments of Lahore (CDGL) and Faisalabad (CDGF), the second and third largest cities of Pakistan respectively. This was supplemented by archival data concerning the delegation of powers, field notes and observations. We identified our interviewees through archival search and subsequently employed a snowball approach (Lincoln and Guba 1985) to identify other managers and so build up our data set. To gain different perceptions of the reforms, interviews were conducted with each level of management (EDO/DEO/DDEO), the political heads of both local government areas and head teachers of secondary and primary schools. Interview questions focussing on the main decentralisation reform objectives including: decentralised managerial autonomy, financial and human resource autonomy, performance management arrangements, community involvement in education services and private/third sector involvement in service delivery. The breakdown of interviewees (level, designation and number interviewed) is provided in table 2. 
[Insert table 2 here]

\section{Data Analysis}

Initially, data analysis was based on identifying first order categories from each interview. These categories were then subjected to thematic coding which allowed the examination of similarities and differences in the data leading to the identification of second order themes using the constant comparison method (Strauss \& Corbin, 1998). For example, the data suggested that managers were constantly under pressure to deliver services with limited resources which could affect the level of discretion used. As a result the theme 'resource constraints' was developed. In another example, we noted that managers often talked about the need for a change in the culture of local government which remained from the previous top-down bureaucracy. Here the theme 'cultural inertia' was developed to describe the problems this caused. Data analysis was an process iterative involving switching between theory and data until no more themes were identified and theoretical saturation was reached (Golden-Biddle and Locke 2007). From the analysis, eight second order themes were identified. Finally, our second order themes were then condensed into more meaningful themes that formed overarching or aggregate dimensions linked with theory. The authors worked separately and then jointly on the analysis and interpretation of the findings to ensure consistency in interpretation. NVivo software aided data analysis providing flexibility to reduce or expand initially generated themes and linking various themes together.

Our data analysis revealed three overarching dimensions associated with the implementation of the reform policy: organisational readiness, willingness for policy adoption and implementation praxis. In the findings sections that follow, we examine 
these three dimensions in relation to the broad policy intention of the reforms for education. Figure 2 summarises the process of data analysis using a data structure table which includes our first order categories, second order themes and aggregate dimensions as set out by Goia et al. (2012). The analysis is supported with interview quotations in order to illustrate our interpretation of the data. Table 3 displays additional illustrative quotes.

[Insert figure 2 and table 3 Here

\section{Findings}

\section{Organisational readiness}

Organisational readiness was the extent that education department was ready to implement the reforms and allowed our managers to use their discretion in decision making. Three themes were associated with organisational readiness: the local government context, capacity building and resource constraints faced by the implementing organisation.

Local government context: policy reform sought to increase user involvement through SCs, and the AAS and were largely dependent on local contextual factors. For instance, EDOs had a positive perception of SCs and suggested how they would be able to facilitate discretion to improve their education service delivery:

Before school councils, schools were always looking to the government for finances or approval to improve missing facilities. Now the school council has their own budget which they can spend according to their needs and do not need approval from the top. The creation of school councils has two main impacts, firstly, it has been able to reduce the teacher absenteeism and secondly, fund utilization is improved. (EDO, CDGF)

This was confirmed by one of the head teachers interviewed: 
With the establishment of school council we are able to mobilize community for instance, once we need to repair the roofs of our school building, we raised $20 \%$ with the help of the community and then rest of the $80 \%$ was provided by the government. (Head Teacher (6) FSBD)

However, DEOs had a different perspective on SCs noting that the demographic characteristics of local communities and the actors involved in service delivery were complex leading to variation in SC use for school improvements:

School councils are not very effective because the community lacks awareness with respect to their role in school council or they do not want to take an interest. For example, if there is a meeting of the school council, usually, community members will not attend this meeting and will ask the head teacher to send the register to their homes for signs. There are some areas where school councils are very active but very rare. The government has done all to improve community participation, but the response from community is not very positive. (DEO, (9) CDGL).

Rural areas in particular had less success with SCs. Here, the literacy rate was lower and communities lacked a basic awareness regarding their role in the SC. In such cases head teachers became the sole authority which could lead to the temptation for corruption or embezzlement of school funds:

The community is very active since decentralization in school councils. However, it varies from area to area. Urban and rural areas have a different environment. In rural areas, due to the lack of education and awareness among the community regarding their role in the school council, school councils are not very active. Generally, in these areas control remains with the head of the institutions. In urban areas school councils help schools in finances plus moral support. (DDEO (F 15) CDGL)

This provided DDEOs with the opportunity to exercise discretion by closely monitoring head teachers involved with SCs for the misuse of funds. DDEO discretion could be used, for example, to stop school funding where incidents of corruption or the 
misuse of authority of head teachers was reported. Where performance was poor, discretion could be used to stop teacher salaries, demote or transfer teachers to other areas.

Another policy initiative was the use of partnerships through the AAS. In cases where the CDG and NGO believed in collaborative arrangements and were commitment to the policy, they were more active in using the AAS. For example, CDGF was the first district in Pakistan to embrace AAS's as a key policy goal in 2006 mobilising the third sector, local communities and local industry in the provision of education service.

Political support in CDGF was also evident allowing managers to gain more commitment in making these policies work.

The City district Government Faisalabad is the first district in the entire country to legitimize a partnership policy framework from the district council CDGF on December 31, 2004. (Political Head of CDGF)

However, similar perceptions were not shared equally amongst all mangers across our CDGs. Despite enthusiasm for the AAS at EDO level, DEOs and DDEOs of both CDGs could at time be frustrated with the AAS and subsequent day to day working arrangements of partners. This was due to a lack of role clarity between the NGOs and education departments which was eventually resolved:

Once the scheme of AAS was started, there were uncertainties among the staff of that school that may be the NGO s are going to be another authority over them. But slowly and gradually, this misperception was removed and now we are quite clear with respect to their roles. Their main purpose was to facilitate learning, provide missing facilities, and improve staff shortage. Then, these NGO s tried to monitor staff, which raised various issues as it was not their role to monitor. Now we have clarified this issue, if they are not satisfied with any of the teacher they come to us and then we try to check their complaint and take action accordingly. (DEO 9 (F) CDGL) 
Capacity building: working with the local community and NGOs required a different skill set in how to reach out to local partners and deal with the difficulties of consulting communities and NGOs. Comparing both CDGs, we found that CDGF took more of an initiative in providing partnership training for their managers, teachers and head teachers allowing better partner management with SC's, the third sector and their community.

We established an Institute of Learning with the help of corporate sector which provides training to the teachers and for the school council members. (EDO, CDGF)

This paid off in that SCs could be used as a strategic tool to meet school needs through raising funds for school improvements. For example, according to the EDO for CDGF, local government allocated Rs.300,000 to the 245 WSD schools in rural and urban areas with $10 \%$ of this fund from community contributions. In this way, DDEOs had some discretion in empowering their schools to manage their resources more effectively so reducing the need to rely on the state for all project funding: a point we return to later. Nevertheless, increased user involvement and collaborative service delivery arrangements did expose managers to more pressure with their ability to exercise discretion dependent on how well they understood the challenges and relationships between different actors and how their work impacted the operation of these structures and processes.

Resource constraints: a key area in the exercise of discretion was the ability to commit resources to the delivery of education services. The reforms created new roles and responsibilities while introducing new reporting mechanisms. However, this was not accompanied with an adequate infrastructure or resources. This limited managerial 
discretion, an area noted in the implementation literature as causing policy failure (Hill, 2003). For example, DDEOs indicated that there were many schools that they had to inspect under their jurisdictions but they were not provided with adequate transport facilities to carry out their jobs effectively:

I have to visit too many schools (345 schools) which are not humanly possible .If I visit a school once, that school become relaxed as they know we will not be able to check them for another 4-5 months. Some of the schools are in such remote areas that we are not able to make frequent visits to them. This is one of the reasons that schools are not performing well, as they (schools) know we cannot monitor them properly. (DDEO (7) CDGF)

DEOs also noted that their work had also become increasingly challenging due to the vagueness in financial rules and procedures and a lack of knowledge regarding their operation. There was though a general agreement among DEOs and DDEOs that engaging local communities was essential if they wanted to bring change to their schools with DEOs in particular using the reform policy to mobilise school involvement to find ways to engage communities that addressed school issues through SCs. DEOs highlighted that during school visits, they tried to encouraged the local community to engage with the SC to raise finance to meet their resource problems which led to positive levels of engagement with the local community and school more generally:

Now the city district government has allocated school councils their own funds and people know that during school council meetings they are being consulted on various issues so they participate in those meetings. $70 \%$ of the school council members attend school council meetings. ----They are monitoring our schools, which has improved the transparency of the utilization of school funds and teacher attendance. In some cases they have even raised funds for school buildings. (DEO (F 11) CDGL)

In sum organisational readiness allowed for some discretion for our managers as SLBs with efforts in capacity building providing skills in engagement for managers to foster 
relationships with partners. While resource constraints often limit the use of discretion building positive relationships with schools and local communities were used to raise funds so reducing the need for central funding requests.

\section{Willingness for policy adoption}

Our second overarching dimension, willingness for policy adoption, focused on specific issues associated with our managers' willingness to implement the reform policy and how much this affected their discretion. Three themes were identified: policy design, stakeholder values and attitudes and cultural inertia.

Policy design: the reform policy was intended to allow substantial decentralisation of decision making to local levels. Our interviews with EDOs identified that reform implementation required a decoupling of the pre-reform culture with its top down decision-making approach from the new reforms. This was not happening. DDEOs stated their frustration with this and that the decision-making process was devoid of a participative approach so creating an indifference to implementing the new arrangements:

We are not involved in the decision making process at any forum. During departmental meetings we are not given opportunity to give our input, it is more obedience focused. Whatever our superiors ask us to do, we do it. (DDEO (7) CDGF)

This lack of involvement resulted in a loss of clarity on a number of policy issues which is characteristic of implementation failure (May and Winter 2009; May 2015). For example, all managerial levels reported concerns regarding the lack of clarity in financial rules and overbearing external audits as one of the key factors that limited financial discretion and led to an under utilisations of development budgets. EDOs 
reported that the auditing system could lead to additional pressure and workload which restricted a desire to make spending requests. Nevertheless, there were instances when managers did at times base discretion on normative choices of 'who is worthy of help' discretion as ineradicable (Soss et al 2011) rather than on government criteria and bent rules to make exceptions:

Financial rules are not very clear. This is one of the reasons of underutilization of funds, people fear that if they spend utilized funds, then they may face an audit Para. Take for example, we needed to sanction scholarship worth 50 lace rupees. The District Co-ordinating Officer did not do it himself and asked me to do it. I did it. The result was the audit Para asking for an explanation. However, at the end it was all settled. (EDO, CDGF)

The extent managers were committed to implement policies was also dependent on whether they perceived policies were feasible to implement. Any psychological disconnect from policy led to policy alienation (Timmers 2013) creating a commitment gap. For instance, managers revealed that at times they could face problems with policy implementation as policy makers had not thought out the challenges faced at the practice level. Referring to experience in relation to community and third sector engagement, the EDO of Faisalabad commented that:

The main problem is that policies are not properly implemented. For example, a scheme was launched under the name of CPP (community public partnership). Under this arrangement, it was proposed that the primary schools should be converted into middle schools in the evening, middle schools should be upgraded to high schools and secondary schools should be upgraded to higher secondary schools. Government was supposed to provide the building and operation and maintenance was to be performed by community. The outcome of this scheme was people who participated in this partnership could not bear the cost at the end. If it had been done in stepwise, it would have been better. It was a good policy but Government did not consider the feasibility of this. (EDO, CDGF).

Stakeholders' values and attitudes: EDO experience and values significantly influenced their organisations' commitment to the reforms. The two CDGs were led by 
EDOs with different backgrounds: CDGL was led by an EDO hired through the Pakistan public service commission and directly appointed as the senior manager of its education department. During previous tenure in CDGF, he had led collaborations with the third sector in education services which had positive benefits and who then replicated some of those initiatives in CDGL:

I have tried to replicate a few initiatives at Lahore, for instance, I tried to develop the HRM-IS system here, and school profiling has been computerized. I have also organized financial managerial training. The whole school model has also initiated which targets to improve school from inside out. These are based from my Faisalabad experience. (EDO, CDGL)

The education department of CDGF on the other hand was led by an EDO who had reached the top ladder through hierarchical progression in the teaching profession and had not been exposed to collaborative and networking working which manifested itself in fewer relationship building with different stakeholders. This led to fewer partnerships in CDGL and an indifference to the initiatives of his predecessor. Thus, the commitment of the EDO to reform implementation and professional networking had a role to play in use of discretion. This was not only in securing the necessary political support from within and outside the local government organisation but also helped in influencing organisational members commitment to policy reform. Willingness to adopt reforms was contingent on EDO professional values and prior experience, an area already noted in the literature which highlights how policy preferences (Hill 2003; May and Winter 2009; Rice 2012) or policy alienation (Tummers 2013) shape micro level decisions.

Cultural inertia: organisational culture was another important variable in explaining how managers used discretion and it was noted that there was resistance to 
the reforms in some quarters. This was down to the pre-existing culture of the provincial government. Under the decentralisation reforms, the environment in the education sector shifted to a new world characterized by devolved management, increased user and third sector involvement in service provision. However, although decentralisation brought structural changes, internal practices and attitude to the reforms took time to change. According to the EDO of CDGL, a shift to a bottom up approach to decision making met with resistance from those who had previously enjoyed significant power under the pre-reform arrangements:

The basic impediment to decentralisation is non-conducive and less adaptive organizational culture. We need to bring a change in the organisation culture and transform it from bureaucratic highly centralised system to the one based on democratic values. Rather than powers being centralised at the top, powers should be decentralised down the hierarchy in order to improve organizational performance. (EDO, CDGL)

DEOs confirmed this and argued that the government was asking them to implement initiatives without considering local cultural factors. For example, school instruction delivered in English was gradually introduced as a key education policy which was found to be particularly challenging to implement:

People do not accept change as it is, they resist it. For instance, recent government initiatives regarding English as a medium of instruction' has met with resistance from teachers and education department. Government has not envisaged the practical considerations, what kind of issues and challenges our teacher will face. They are not ready for it.... There should be democratisation of education.....we should be involved in the process of making such policies as we are more aware of the issues at the service level. (DEO (3), CDGF).

Summarising, willingness for policy adoption played an important role in explaining managerial behaviour as SLBs. We noted that managers felt that the reform process had 
not been given enough practical thought and lacked commitment by government in relation to the need to change existing culture to be more democratic. Previous experience and professional networks allowed a degree of discretion in decision making with existing cultural norms impacting on the implementation agenda.

\section{Implementation praxis}

Our third aggregate dimension, implementation praxis, focussed on the practicalities of managerial discretion when implementing the Musharraf reforms (Brodkin and Majmundar 2010). Three themes were identified that focussed on the practicalities of discretion: bureaucratic control, role ambiguity over the reform policy and power plays in vetting local decision making.

Bureaucratic control: while education service delivery was devolved to the education departments and provided managers with administrative and financial powers, managers stated that the provincial bureaucracy which was responsible for education service delivery in the previous system, did not want to let go of power and tried to curtail local government decision making. For example, in 2006 the delegation of powers was amended with financial powers transferred to District Coordinating Officers who were in overall control of local government removing spending discretion from the EDOs (Khan and Munawar 2011).

Powers have been centralised in the District Coordinating Officer rather than the technical person who understand ground realities and the frontline issues in education service delivery'. (EDO, CDGL)

This resulted in a power struggle between EDOs, local politicians and the local bureaucracy. Nevertheless, within this rule-bound system, EDOs did find ways to cope with these difficulties and exercise some discretion. For example, EDOs would resort 
to offering kickbacks to officials involved in audit inspections to avoid the doing paperwork and subsequent audit objections. Where discretion was used, it would be followed by the provincial bureaucracy using accountability mechanisms to criticise and block the decisions of EDOs:

There are too many agencies involved in checking our performance; however, their attitude is very negative. If you are committed to find what is wrong, you will find everything is wrong. Too many bosses' means there are more doors to skip. (EDO, CDGL)

Role ambiguity: different managerial levels had different perceptions of the extent of choice in exercising their discretion. For the EDOs, delegation of powers were perceived as 'overloading one tier' with more responsibilities, and for other management levels it was perceived as 'writing reports, more paperwork and mundane jobs'. DEOs and DDEOs on the other hand, considered that rather than decentralising power, power was recentralised at the top with the bureaucratic heads of local government having more power. The EDO for CDGL confirmed this stating that development projects were based on bureaucratic whims rather than 'where they are needed' resulting in waste or duplication of resources that again reduced the discretion of lower level managers:

Power plays: despite the administrative and financial discretion devolved to the education departments, the work of managers were heavily influenced by the support received from their political representatives and the bureaucracy at the local level. Although devolution had created a higher administrative status for managers, they faced political and bureaucratic influences which could curtail their discretion, a theme consistent in the literature associated with the policy failure (Hill 2006; Riccicci et al. 
2004). Managers highlighted that although they had more financial autonomy, they had less administrative autonomy. They had the power to spend resources but needed administrative authority to do so. This was more significant at the DDEO level:

On paper, we have administrative and financial discretion, but in practice we just implement the orders of our senior management. Whatever budget proposal we submit, it faces cuts by our senior management. (DDEO, (3) CDGF)

DDEOs thought that at times they were partially empowered but at other times they were only signing authorities following the orders of their superiors with little discretion:

I am partially empowered; decentralization is followed by recentralization of powers at the top. If I want to take any action against those who are not performing well, I will start getting pressure from the top. Therefore I will not be able to take any action. (DDEO,(2) CDGL)

In short, implementation praxis became challenging for managers acting as SLBs due to the continued control exerted by the provincial bureaucracy. This led to conflict and a power struggle with our managers. While financial autonomy was devolved, administrative autonomy was more elusive especially at lower management levels.

\section{Discussion}

Our study has examined policy implementation and local government reform in Pakistan using the context of education services. We have focussed on education managers as SLBs and their role in the policy implementation process. Our research question asked to what extent were managers able to exercise their newly acquired powers of discretion in decision making? In answering our research question we develop a three-stage process based model of policy implementation grounded in our 
data collected from interviews with EDOs, DEOs and DDEOs. We now elaborate on our model and our contribution to the literature. Our model is summarised in Figure 3 and is organised around our three aggregated dimensions that emerged from the data structure summarised in figure 2.

[Insert figure 3 here]

The education reforms had three key elements: the devolution of administrative and financial autonomy to education departments; increasing service-user involvement in service provision through SCs and; allowing the third sector to participate in education service e delivery through the AAS. Our primary contribution is to suggest that managers implemented the Musharraf reforms using what we term enacted discretion. We developed the concept of enacted managerial discretion by building on Soss et al's (2011) 'broad vs deep' discretion and Tummers and Bekker (2014) 'discretion as experienced'. Although the reforms were intended to allow administrative and financial decision making to be devolved locally, this was limited due to constraining factors associated with the reforms including a lack of resources allocated to the reform process, a cultural legacy of top down decision making and attempts by the previous provincial bureaucracy to control decision making - what Evetts (2002) terms discretion with constraints. Enacted discretion allowed a degree of freedom to make decisions which we explain by using the three aggregate dimensions of organisational readiness, willingness for policy adoption and implementation praxis. The first phase, organisational readiness, set out the context of managerial discretion, and underlies that managerial discretion to implement reforms is contingent upon factors such as local government context, and capacity building efforts and resource 
constraints. The core emphasis was that policies needed to take into account of the issues and challenges at the local level that enabled local government organisations and their managers to enact their discretion to implement policy reforms. The literature on SLBs has highlighted resource issues (Lipsky, 1980) referring to terms such as 'enablements' (Hupe and Buffat 2014) and 'management-by enabling' which focus on internal capacity. Organisational readiness extends these concepts by suggesting that the role of the internal and external environment is important in determining the extent managers can enact their discretion as provided to them under the policy reforms and is thus concomitant in making policies work at the practice level. Organisational characteristics aimed at enabling managers to build capacity emerged as a significant influence on developing a clear understanding of the reforms as this further determined the extent managers were willing to enact their discretion to make those reforms work. Reforms such as increased user involvement in service provision exposed managers to more pressures and required a new set of role expectation. Hence, managers' discretion to implement such reforms was largely depended on how well managers understood the challenges associated with such reforms and were equipped with the relevant skill set to cope with such challenges. However, the problem of resource and capacity issues were always a key constraint. For example, while financial resources were devolved, the discretion in using them in the provision of education services was made more challenging by having to gain administrative support higher up - discretion as granted (Hupe and Buffat, 2014). In general, DEOs and DDEOs noted that the resources allocated to the new system were not sufficient to allow it to operate as intended which limited their discretion and was more noticeable at the DDEO level. This links with phase two, willingness for policy adoption. The emphasis in phase two was based on how managers interpreted structural reform, their ability to engage others in the reform 
agenda and their re-construction of policy which affected their levels of commitment and subsequently their willingness for policy adoption. Tummers and Bekkers (2014) contend that SLB willingness to enact their discretion to implement policies increases if they perceive policies to be meaningful for the public which resulted in the greater use of discretion. Our analysis underscores that how far managers were willing to adopt policies and enact discretion depended on the reform policy design, stakeholder values, attitudes to the reforms and cultural inertia. This suggests that a combination of individual, organisational factors and contextual issues may explain the varying levels of managers' willingness to enact their discretion to implement reforms. The lack of willingness to enact discretion results from a lack of clarity regarding policy issues which is further exacerbated by key stakeholders values and prior experiences, particularly if they consider those reforms cannot help their clients, and the pre-existing cultural inertia which resist change. Phase three, implementation praxis, suggests how managers used their discretion in their micro or day to day practice within the constraints of their organisational settings. This particularly highlights that the instances managers were able to resist bureaucratic control through the use of their power play tactics and enact their discretion to make policies work. For instance, EDOs were able to use informal relationships from stages one and two to build social capital to resist political interference seen through ways to circumvent bureaucratic control that deliberately limited discretion from higher levels. For example, managers' emphasis on the use of SCs to raise additional funding for schools rather than completely relying on state funding and the hurdles that this would ensure, what Soss et al (2011) term ineradicable discretion. Political influences could also create a mismatch between intended policy objectives and role constraints that managers faced on their choice of what to follow in practice. We found that the extent managers exercised their discretion 
and coped with political influences was dependent on their leadership skills and ability to network with other professionals and local communities. This was not a linear or sequential process but occurred iteratively as shown by the two feedback loops in figure 3 with managers often going backwards and forwards over time. In this way personal values and knowledge towards the policy reform shaped their approach to policy implementation. While Lipsky (1980) contends that managers only strive to gain SLB compliance and do not pursue their own interests we found that our EDO, DDO and DDEO managers enacted discretion as SLBs in their own right.

Another goal of the Musharraf reforms was increased user and third sector involvement. This was achieved via the SCs and the AAS scheme. However, the successful implementation of these reforms was contingent on our process model as outlined earlier. The use of diverse actors in service provision were perceived by EDOs as a powerful discretionary tool to meet the scarce resource problem education was facing in service delivery. In cases where such an understanding prevailed, managers showed more willingness for policy adoption of such policy initiatives and able to enact their discretion while coping with the issues associated with their organisational readiness. Existing studies examining education reform in Pakistan have noted that the initial response to the reforms was resistance from various stakeholders, particularly bureaucrats who were set to lose their status and power from pre-devolution structures (Jamil 2006; Shah 2003; Zaidi 2005).

Our study is not without its weaknesses. We focussed on two education departments in two of the largest City areas in Pakistan. Future research in other areas of Pakistan local government such as housing or roads, would allow a greater comparison of the utility of the reforms whilst providing cross service comparisons to be made of the success or otherwise of the reform process. Pakistan, due to the 
relationships between its military and civilian government, may also be an extreme case which limits generalisation to other contexts.

\section{Conclusion}

In this paper we have examined policy implementation in a developing country, Pakistan, an area where less empirical work on policy implementation has been carried out. The paper contributes to the literature by focusing on the role of managers as SLBs in their own right, an under researched area. The findings have implications for the theory and practice. For theory, we develop the extant literature on SLBs concerning the paradox of discretion and highlight the role of individual, organisational and contextual factors on the exercise of managerial discretion. Through our process model, we suggest the extent managers were able to enact discretion was dependent on the interactive nature of organisational readiness, willingness for policy adoption and implementation praxis. That is, managers face exactly the same challenges to the use of discretion in policy implementation as SLBs who deliver services face to face with clients

For practitioners, we suggest that policy makers would benefit from a deeper understanding of the nature and context of managers when they propose policy reforms. For example, although the Pakistan local government reforms of 2001 created structural changes, these changes were not accompanied with resources resulting in capability and capacity problems at the practice level. Policy makers often underestimate the role of existing organisational culture and norms and the time it may take to adapt to new practices which is important to determine whether organisations are ready to undertake such challenges or not. What happens in the initial stages of policy implementation is therefore critical in determining what follows afterwards. Hence, policy makers should 
be more aware of day to day challenges of managers as they are also directly involved in the process of implementation. 


\section{References}

Berman, P. The Study of Macro and Micro Implementation of Social Policy. Santa Monica, CA: RAND Corporation, 1978.

https://www.rand.org/pubs/papers/P6071.html.

Bergen, A., and A. While. 2005. Implementation deficit and street-level bureaucracy: policy, practice and change, Health \& Social Care in the Community 13(1): 110.

Bozeman, B., and G. Kingsley. 1998. Risk culture in public and private organizations.

Public Administration Review, 58, 109- 118.

Brehm, J., and J. T. Hamilton. 1996 Noncompliance in Environmental Reporting: Are Violators Ignorant, or Evasive, of the Law? American Journal of Political Science, 40(2): 444-77.

Brodkin, E. Z. 2007. Bureaucracy redux: Management reformism and the welfare state. Journal of Public Administration Research and Theory 17(1): 1-17.

Brodkin, E. Z. 2011a. Putting street-level organizations first: New directions for social policy and management research. Journal of Public Administration Research and Theory 21(suppl 2): i199-i201.

-2011b. Policy work: Street-level organizations under new managerialism. Journal of Public Administration Research and Theory 21(suppl 2): i253-i277.

Brodkin, E.Z., Majmundar, M. 2010. Administrative Exclusion: Organizations and the Hidden Costs of Welfare Claiming, Journal of Public Administration Research and Theory, 20:4, 827-848.

Burrel, G., and G. Morgan. 1979. Sociological Paradigms and Organizational Analysis. London: Heinmann.

Cheema, A., I. Asim, and A. Qadir. 2006. Local government reforms in Pakistan: context, content and causes. Decentralization and Local Governance in Developing Countries: A Comparative Perspective 257-84.

Cheibub, J.A., J. Gandhi, and J.R. Vreeland. 2010. Democracy and dictatorship revisited. Public Choice, 143(1-2), pp.67-101.

Cheung, A. BL. 2005. The politics of administrative reforms in Asia: Paradigms and legacies, paths and diversities. Governance 18(2): 257-282.

Cloutier, C., J. L. Denis, A. Langley, and L. Lamothe. 2016. Agency at the managerial interface: public sector reform as institutional work. Journal of Public Administration Research and Theory 26(2): 259-276.

Cohen C. 2018. How Culture Affects Street-Level Bureaucrats' Bending the Rules in the Context of Informal Payments for Health Care: The Israeli Case. American review of public administration, 48:2, 175- 187.

Crosby, B. L. 1996. Policy implementation: The organizational challenge. World Development 24(9): 1403-1415.

Cyan, M., D. Porter, H. Sharif, J. Charlton, Z. Hasnain, and N. Manning. 2004. Devolution in Pakistan. Islamabad: ADB.

Dawn Newspaper. January 20, 2002: Body set up to focus on education, health, poverty alleviation. https://www.dawn.com/news/15827/body-set-up-to-focus-oneducation-health-poverty-alleviation.

DeLeon, P., and D. Linda . 2002. What ever happened to policy implementation? An alternative approach. Journal of Public Administration Research and Theory: $J$ PART: 467-492.

Demirel, T. 2005. Lessons of military regimes and democracy: the Turkish case in a comparative perspective. Armed Forces \& Society, 31, pp.245-271. 
Durose, C. 2011. Revisiting Lipsky: front-line work in UK local governance. Political Studies 59(4): 978-995.

Edmondson, A. C., and S.E. McManus. 2007. Methodological fit in management field research. Academy of Management Review 32(4): 1246-1264.

Evans, T. (2010). Professional discretion in welfare services. Aldershot: Ashgate.

Evans, T. 2015. Street-level bureaucracy, management and the corrupted world of service. European Journal of Social Work: 1-14.

2011. Professionals, managers and discretion: Critiquing street-level bureaucracy. British Journal of Social Work 41(2): 368-386.

Evetts, J. 2002. New directions in state and international professional occupations:

Discretionary decision-making and acquired regulation, Work, Employment and Society, 16:2, 341-53.

Goel, S. 2014. Bureaucratic Attitudes' - an Intermediary Variable of Policy

Performance. Vision: The Journal of Business Perspective 18(4): 299-308.

Goia, D., K. Corley, and A. Hamilton. 2012. Seeking rigot in qualitative inductive research: notes on the Goia methodology. Organizational Research Methods 16(1): 15-31.

Golden-Biddle, K., and K. Locke. 2007. Composing Qualitative Research. London: Sage.

Government of Pakistan. 2000. Local government plan 2000. Islamabad: National Reconstruction Bureau (NRB).

Government of Pakistan. 2007. Delegation of financial powers Punjab: Islamabad.

Government of Punjab. 2001. Punjab Local government Ordinance (XIII OF 2001). Revised Edition. Islamabad: National Reconstruction Bureau (NRB).

Grindle, M. S. 1980. Politics and Policy Implementation in the Third World. Princeton, NJ: Princeton University Press.

Hill, H. C. 2003. "Understanding Implementation: Street-Level Bureaucrats' Resources for Reform." Journal of Public Administration Research and Theory 13(3): 265282.

Hill, C. J. 2006. Casework job design and client outcomes in welfare-to-work offices. Journal of Public Administration Research and Theory 16(2): 263-288.

Hull, C., and B. Hjem. 1987. Helping Small Firms Grow. London: Croom Helm.

Honig, M. I. 2006. Street-level bureaucracy revisited: Frontline district central-office administrators as boundary spanners in education policy implementation. Educational Evaluation and Policy Analysis 28(4): 357-383.

Hupe, P., and M. Hill. 2007. Street-Level bureaucracy and public accountability. Public Administration 85(2): 279-299.

Hupe, P., and A. Buffat. 2014. A Public Service Gap: Capturing contexts in a comparative approach of street-level bureaucracy. Public Management Review 16(4): 548-569.

Kardar, S. 2006. Local government Finance in Pakistan Post 2001. The Lahore Journal of Economics.

Khan, M. A., and S.M. Munawar (2011)_Implementation of Decentralization in Education in Pakistan: Framework, Status and the Way forward. Journal of Research and Reflections in Education, December 2011, 5(2):146 -169.

Keefer, P., A. Narayan, and T. Vishwanth. 2003. The Political Economy of Decentralisation in Pakistan. World Bank, Development Economics, Policy Research Group: Washington, D.C. 
Keiser, L. R. 2010. Understanding Street-Level Bureaucrats' Decision Making: Determining Eligibility in the Social Security Disability Program. Public Administration Review 70(2): 247-257.

Keiser, L. R., and J. Soss. 1998. With good cause: Bureaucratic discretion and the politics of child support enforcement. American Journal of Political Science 42(4): 1133-1156.

Kwon, O. Fiscal decentralization: An effective tool for government reform? 2013 Public Administration 91 (3): 544-560.

Jalal, A., 1995. Democracy and Authoritarianism in Pakistan: A Comparative and Historical Perspective. Sang-e-Meel Publishers: Lahore.

Jamil, B. 2006. Decentralization and devolution in Pakistan: Educational implications of the praetorian interpretation. in Educational Decentralization, pp. 191-209. Springer.

Lasswell, H. D. 1958. Politics: Who Gets What, When, How. Cleveland, OH: World Publishing

Lipsky, M. 2010. Street-Level Bureaucracy, 30th ann. Ed.: dilemmas of the individual in public service. New York: Russell Sage Foundation.

Lipsky, M. 1980. Street Level Bureaucracy. New York: Russell Sage.

Lin, A.C. 2002. Reform in The Making: The Implementation of Social Policy in Prison. Princeton, NJ : Princeton University Press.

Lincoln, Y. S., and E. G. Guba. 1985. Naturalistic Inquiry. London: Sage.

Manning, N., D. Porter, J. Charlton, M. Cyan and Z. Hasnain. 2003. Devolution in Pakistan Preparing for Service Delivery Improvements. Pakistan: World Bank.

Matland, R.E. 1995. Synthesizing the implementation literature: The ambiguity-conflict model of policy implementation. Journal of Public Administration Research and Theory 5(2): 145-174.

May, P. J. 2015. Implementation failures revisited: Policy regime perspectives. Public Policy and Administration 30(3-4): 277-299.

May, P. J., and S.C. Winter. 2009. Politicians, managers, and street-level bureaucrats: Influences on policy implementation. Journal of Public Administration Research and Theory 19(3): 453-476.

Maynard-Moody, S., and. Musheno, M.C. 2003. Cops, teachers,counsellors: Stories from the front lines of public service. Michigan: University of Michigan Press.

Meier, K. J. 1993. Latinos and representative bureaucracy testing the Thompson and Henderson hypotheses. Journal of Public Administration Research and Theory 3(4): 393-414.

Meier, K. J., L. J. O'Toole, and S. Nicholson-Crotty. 2004. Multilevel governance and organizational performance: investigating the political-bureaucratic labyrinth. Journal of Policy Analysis and Management 23(1): 31-47.

Miles, M. and M. Huberman. (1994) Qualitative Data Analysis (second edition). Beverly Hills, CA: Sage.

Ministry of Education. 2002. Education Sector Reforms Action Plan 2001-2005. Islamabad: Government of Pakistan

Meyers, M. K. and L. Nielsen. 2012. Street-Level Bureaucrats and the Implementation of Public Policy. In Handbook of Public Administration, 2nd ed, Edited by: Peters, B. G. and Pierre, J. 305-18. London: Sage Publications.

Najam, A. 1995. Learning from the Literature on Policy Implementation: A Synthesis Perspective. IIASA Working Paper. IIASA, Laxenburg, Austria: WP-95-061.

National Reconstruction Bureau,NRB. 2000. Local government: Proposed Plan. National Reconstruction Bureau: Islamabad, Pakistan. 
Newman, J. 2000. Beyond the new public management? Modernizing public services. New Managerialism, New Welfare 28: 45-61.

O'Toole, L. J. 2000. Research on policy implementation: Assessment and prospects. Journal of Public Administration Research and Theory 10(2): 263-288.

Osborne, S. P. 2006. The new public governance? 1. Public Management Review 377387.

Paracha, A. 2003. Devolution plan in Pakistan: context, implementation and issues. Open Society Institute:Budapest.

Piore, M. J. 2011. Beyond Markets: Sociology, street-level bureaucracy, and the management of the public sector. Regulation \& Governance, 5(1): 145-164.

Pressman, J. L., and A. B. Wildavsky. 1973. Implementation: How Great Expectations in Washington are Dashed in Oakland; Or, why It's Amazing that Federal Programs Work at All. University of California Press: Berkeley.

Rice, D. 2012. Street-level bureaucrats and the welfare state: Toward A Micro Institutionalist Theory of Policy Implementation. Administration \& Society 45(9):1038-62.

Riccucci, N.M., M.K. Meyers, I. Lurie. and J. S. Han. 2004. The Implementation of Welfare Reform Policy: The Role of Public Managers in Front-Line Practices. Public Administration Review 64(4): 438-448.

Romzek, B. S., K. LeRoux, and J.M. Blackmar. 2012. A preliminary theory of informal accountability among network organizational actors. Public Administration Review, 72: 442-453.

Sabatier, P. A. 1991. Toward better theories of the policy process. PS: Political Science \& Politics 24(2): 147-156.

Sabatier, P. A. 1986. Top-down and bottom-up approaches to implementation research: a critical analysis and suggested synthesis. Journal of public policy 6(1): 21-48.

Sabatier, P. A. 1991. Towards better theories of the policy process. PS: Political Science and Politics 21: 147-56

Sandfort, J. R. 2000. Moving beyond discretion and outcomes: Examining public management from the front lines of the welfare system. Journal of Public

Administration Research and Theory 10(4): 729-756.

Shah, D. 2003. Country report on decentralization in the education system of Pakistan: Policies and strategies. Islamabad: Academy of Educational Planning and Management,(Islamabad), Ministry of Education.

Strauss, A., and J. Corbin. 1990. Basics of Qualitative Research. Newbury Park, CA: Sage.

Strategic Operation Unit (SPU). 2008, Strategic Operation Plan 2008. Faisalabad: District Government Faisalabad.

Soss, J, Richard F., and Sanford F. Schram. 2011. The Organization of Discipline: From Performance Management to Perversity and Punishment. Supplement 2, Journal of Public Administration Research and Theory 21: 203-32.

Stensöta, H.O. 2012. Political Influence on Street-Level Bureaucratic Outcome: Testing the Interaction between Bureaucratic Ideology and Local Community Political Orientation, Journal of Public Administration Research and Theory, $22: 3,553-571$.

Taylor, I., and J. Kelly. 2006. Professionals, discretion and public sector reform in the UK: re-visiting Lipsky. International Journal of Public Sector Management 19(7): 629-642. 
Taylor, I. 2007. Discretion and Control in Education The Teacher as Street-level Bureaucrat. Educational Management Administration \& Leadership 35(4): 555572.

Tummers, L. (2012) "Policy Alienation of Public Professionals: The Construct and Its Measurement." Public Administration Review 72 (4): 516-525.

Tummers,L., Vermeeren, B., Steijn, B., and Bekkers, V. 2012. Public Professionals and Policy implementation, Public Management Review, 14:8, 1041-1059.

Tummers, L., and Bekkers, V. (2014) Policy Implementation, Street-level Bureaucracy, and the Importance of Discretion, Public Management Review, 16:4, 527-547.

Rice, D. 2013. Street-Level Bureaucrats and the Welfare State Toward a MicroInstitutionalist Theory of Policy Implementation. Administration \& Society 45(9): 1038-1062.

Van Meter, D.S., and Van Horn, C.E. 1975. The Policy Implementation Process: A

Conceptual Framework. Administration and Society, 6:4, 445-88

Van Parys, L., and L. Struyven. 2018. Interaction styles of street workers and motivation of clients: a new instrument to assess discretion-as-used in the case of activation of jobseekers. Public Management Review 20(11), 1702-1721, DOI: $10.1080 / 14719037.2018 .1438501$

Wellstead, A., and R. Stedman. 2010. Policy Capacity and Incapacity in Canada's Federal Government: The intersection of policy analysis and street-level bureaucracy. Public Management Review 12(6): 893-910.

Wilder, A. 1999. The Pakistani Voter:Eelectoral Politics and Voting Behaviour in the Punjab. Oxford: Oxford University Press.

World Bank. 2007. Implementation Completion and Results Report on an Education

Sector Development Policy Credit, Report Number ICR0000434. World Bank:

Washington DC.

Yin, R. K. 2015. Qualitative research from start to finish. Guilford Publications.

Zaidi, S. A. 2005. The political economy of decentralisation in Pakistan. NCCR NorthSouth. 
Figure 1. New institutional arrangement following the Devolution Plan 2001

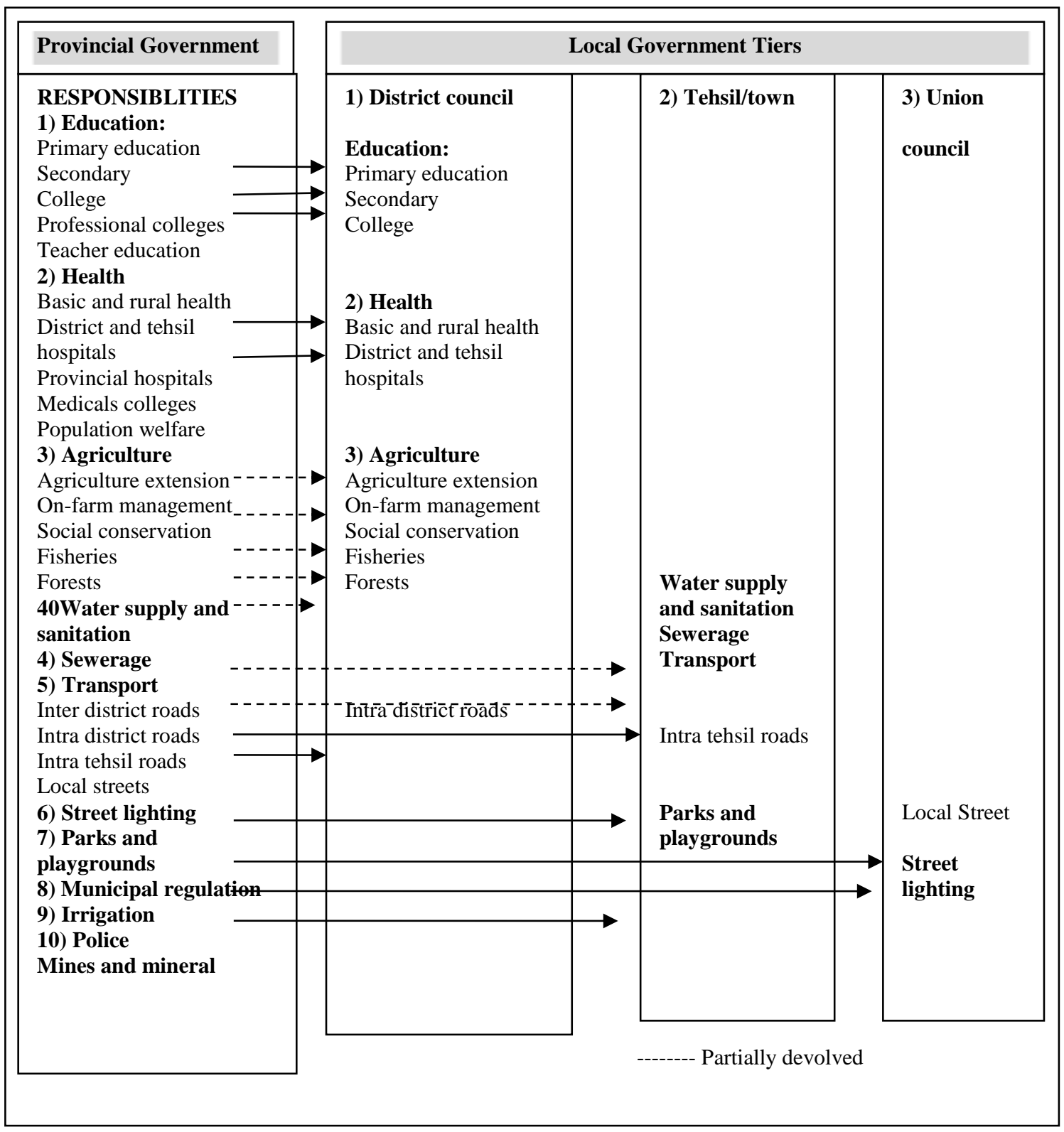




\section{Table 1: Roles and Responsibilities of interviewees following the Local government Reforms}

\begin{tabular}{|c|c|c|}
\hline Managerial level & Administrative powers & Financial powers \\
\hline EDO - Executive District Officer & $\begin{array}{l}\text { - Supervision and coordination of all wings of education in the district. } \\
\text { Review annual performance of the district officers and subordinate staff, } \\
\text { identify employee training needs, arrange training program for them, take } \\
\text { disciplinary action for maintaining good discipline in its schools } \\
\text { (EDO was the head of the Education Department and was a newly } \\
\text { created post under Local government reform 2001. Pre-devolution, } \\
\text { education department was under the provincial supervision) }\end{array}$ & $\begin{array}{l}\text { Preparation and execution of the Annual development Plan, } \\
\text { - Internal audit and settlement of those audit objections, } \\
\text { - Sanctions of pensions fund up to grade } 19-20\end{array}$ \\
\hline $\begin{array}{l}\text { DEO (SE) - District Education } \\
\text { Officer } \\
\text { Secondary Education (Grade 9- } \\
\text { 12) }\end{array}$ & $\begin{array}{l}\text { - } \quad \text { Registration of private secondary schools } \\
\text { - } \quad \text { Internal inspection and audit of the institutions } \\
\text { - } \quad \text { (Prior to decentralisation, director of secondary education was responsible } \\
\text { for the posting, transfers, promotion and registration of secondary schools } \\
\text { in the district) }\end{array}$ & $\begin{array}{ll}\text { - } & \text { Preparation of annual development plan } \\
\text { - } & \text { Grant of pension funds (GP funds) up to BS } 18 \\
\text { - } & \text { Reimbursement of medical charges up to BS } 17 \\
& \text { Award of scholarships }\end{array}$ \\
\hline $\begin{array}{l}\text { DEO (EE) - District Education } \\
\text { Officer } \\
\text { Elementary/Primary Education } \\
\text { (Grade 1-8) }\end{array}$ & $\begin{array}{ll}\text { - } & \text { Appointment authority of elementary teachers } \\
\text { - } & \text { Promotion of teaching staff } \\
\text { - } & \text { Issuance of retirement notification } \\
\text { - } & \text { Transfer of teaching staff } \\
\text { - } & \text { Ensure proper functioning of school councils } \\
\text { - } & \text { Registration of primary and elementary private school } \\
\text { - } & \text { Conduct examinations }\end{array}$ & $\begin{array}{l}\quad \text { Preparation and execution of annual development } \\
-\quad \text { Grant of pensions funds advance } \\
\text { - Sanctions of pensions, medical reimbursement claims, grant of } \\
\text { medical leave }\end{array}$ \\
\hline $\begin{array}{l}\text { DDEO - Deputy District } \\
\text { Education Officer }\end{array}$ & $\begin{array}{ll}\text { - } & \text { Appointment of non-teaching staff } \\
\text { - } & \text { Ensure proper functioning of school councils } \\
\text { - Sanction leave of head teachers of elementary schools and Assistant } \\
\text { - } \quad \text { Sanction officer (AEO) } \\
\text { - Forward cases of teave and ex-Pakistan leave of PTC teachers } \\
\text { Figher authorities }\end{array}$ & $\begin{array}{l}\text { - } \quad \text { Drawing and disbursement officers } \\
\text { - } \quad \text { Release of salaries to teaching staff } \\
\text { - } \quad \text { Preparation of contingency plans for their schools } \\
\text { - } \quad \text { Preparation and execution of budget of its own staff } \\
\text { - } \quad \text { Collection and monitoring of budget of its own staff } \\
\text { - } \quad \text { Pellection and monitoring of financial data from the institutions } \\
\end{array}$ \\
\hline
\end{tabular}

Source: compiled from internal reports (Delegation of financial powers Punjab, 2006) and document of World Bank 2007 
Table 2. Interviewees: designation, location and number

\begin{tabular}{|c|c|c|c|}
\hline $\begin{array}{l}\text { Managerial } \\
\text { level }\end{array}$ & $\begin{array}{l}\text { Designation / Responsibilities } \\
\text { Managerial Level }\end{array}$ & CDGL & CDGF \\
\hline $\begin{array}{l}\text { Top Management/ } \\
\text { Head of the } \\
\text { Education } \\
\text { Department }\end{array}$ & Executive District Officer & 1 & 1 \\
\hline \multirow[t]{4}{*}{ Senior Management } & $\begin{array}{l}\text { District education officer(Male/Elementary } \\
\text { education) }\end{array}$ & 1 & 1 \\
\hline & $\begin{array}{l}\text { District education officer(Female/Elementary } \\
\text { education) }\end{array}$ & 1 & 0 \\
\hline & $\begin{array}{l}\text { District education officer(Male/Secondary } \\
\text { education) }\end{array}$ & 1 & 1 \\
\hline & $\begin{array}{l}\text { District education officer(female/Secondary } \\
\text { education) }\end{array}$ & 1 & 0 \\
\hline \multirow[t]{4}{*}{$\begin{array}{l}\text { Middle } \\
\text { management }\end{array}$} & $\begin{array}{l}\text { Deputy District Education Officer } \\
\text { (male/elementary) }\end{array}$ & 4 & 1 \\
\hline & $\begin{array}{l}\text { Deputy District Education Officer } \\
\text { (female/elementary) }\end{array}$ & 2 & 3 \\
\hline & $\begin{array}{l}\text { Deputy District Education Officer } \\
\text { (male/secondary) }\end{array}$ & 0 & 1 \\
\hline & $\begin{array}{l}\text { Deputy District Education Officer (female } \\
\text { /Secondary }\end{array}$ & 1 & 0 \\
\hline \multirow[t]{3}{*}{ Head teachers } & Female (Secondary School) & 1 & 1 \\
\hline & Female (Primary School) & 1 & 1 \\
\hline & Male (Primary School) & 1 & 1 \\
\hline Political Heads & & 1 & 1 \\
\hline
\end{tabular}


Figure 2. Data structure: categories, themes and dimensions

\section{1st Order Categories}

\begin{tabular}{|l|}
\hline Financially autonomous local government face less resource \\
constraints when faced with economic instability in the \\
\hline Characteristics of local community affect their engagement \\
\hline Support from government and societal stakeholders \\
\hline
\end{tabular}

Capacity building of stakeholders - how to implement policies, Lack of knowledge, IT- information consolidation

Lack of information on policies reforms Vagueness in rules and procedures.

Workload pressure affects inspection of all the schools, too many schools to visit; Hard to reach areas less monitored

Adhocism in the system - change in governments lead to discontinue previous policies

Relabelling old policies

Short term approach to policy implementation

Employees' attitude to change - people do not like change, Work ethics,

Non adaptive organisational culture to democratic values, open communications

Unlearning prior assumptions - transformation from to down to decentralise system

Democratic cultural values do not persist

Stakeholders' engagement

\begin{tabular}{|l|}
\hline Discretion controlled through rules and procedures \\
\hline Powers curtailed through amendments in the LGO 2001 \\
\hline $\begin{array}{l}\text { Discretion curtailed through blaming competence of the staff } \\
\text { Budget cuts, Audit objections }\end{array}$ \\
\begin{tabular}{|l} 
Discretion means emphasis on writing reports, paperwork- \\
report writing perceived as additional work \\
Supervisors assign additional workload \\
Mundane jobs passed down to the lower levels not actual \\
policy making
\end{tabular} \\
\hline
\end{tabular}

Senior management control hiring and posting of staff Political elites influence hiring, firing\& posting/transfer of staff

Personal networking with internal and external stakeholders Political and professional background 2nd Order Themes

Aggregated

Organisational

Readiness
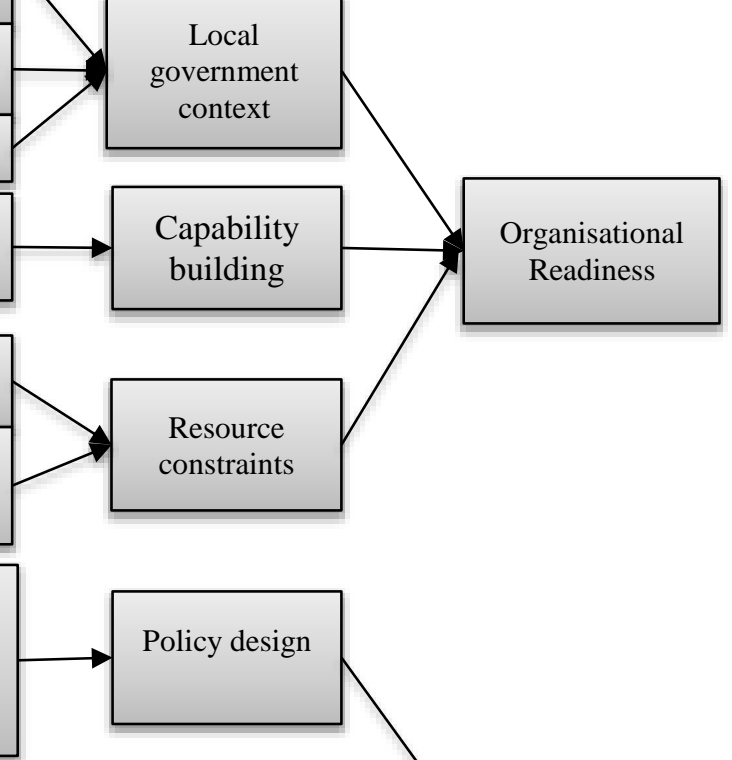


\section{Table 2. Selected examples of aggregate dimensions, categories and themes}

\begin{tabular}{|c|c|}
\hline Aggregated themes & Representative quotes \\
\hline \multicolumn{2}{|l|}{$\begin{array}{l}\text { Organisational } \\
\text { Readiness }\end{array}$} \\
\hline $\begin{array}{l}\text { 1. Local government } \\
\text { context }\end{array}$ & $\begin{array}{l}\text { A1. Under the current economic instability, we are facing financial constraints because of provincial governments freezing Local government budgets. } \\
\text { We are unable to pay teachers' salaries since last six months. (DDO (M-5) CDGF) }\end{array}$ \\
\hline $\begin{array}{l}\text { 2. Resource } \\
\text { constraints }\end{array}$ & $\begin{array}{l}\text { B1. I have to visit too many schools ( } 345 \text { schools). Mostly if I visit a school it becomes relaxed for another } 4-5 \text { months as they know I will not be able } \\
\text { to check them. Some schools are in such remote hard to reach areas that we are not able to visit them frequently. This is one of the reasons that schools } \\
\text { in remote areas are not performing very well. (DDO, (F-8) CDGF) }\end{array}$ \\
\hline 3. Capacity building & $\begin{array}{l}\text { C1. Training of DEO and DDEO should be organized regarding budgeting financial management at all levels. Training has been organized but it } \\
\text { should be regular basis. People should be given more orientation regarding new intervention for strong checks and balances. (EDO, CDGL) }\end{array}$ \\
\hline \multicolumn{2}{|l|}{$\begin{array}{l}\text { Willingness for policy } \\
\text { adoption }\end{array}$} \\
\hline 4. Policy design & $\begin{array}{l}\text { D1. Policies are not properly implemented because policy maker do not take into account challenges that we face at the practice level. They want us to } \\
\text { implement policies revamping the old system without considering the feasibility of that policy, how to do that. Whereas if we adopt an incremental or } \\
\text { phased approach we have more chances of successful implementation. (EDO, CDGF) }\end{array}$ \\
\hline $\begin{array}{l}\text { 5. Stakeholders values } \\
\text { and attitudes }\end{array}$ & $\begin{array}{l}\text { E1. School councils are very effective way of engaging community in service provision, financing and transparent utilization of school funds. } \\
\text { However, it is more effective where people are less segregated in status or regional difference, and people are more educated. (DDO (1) CDGF). }\end{array}$ \\
\hline 6. Cultural inertia & $\begin{array}{l}\text { F1. The basic impediment to decentralisation is non-conducive and less adaptive organizational culture. We need to bring a change in the organisation } \\
\text { culture and transform it from bureaucratic highly centralised system to the one based on democratic values. Rather than powers being centralised at the } \\
\text { top, powers should be decentralised down the hierarchy in order to improve organizational performance. (EDO, CDGL) }\end{array}$ \\
\hline
\end{tabular}




\begin{tabular}{|c|c|c|}
\hline & \multicolumn{2}{|l|}{$\begin{array}{l}\text { Implementation } \\
\text { Praxis }\end{array}$} \\
\hline & Bureaucratic control & $\begin{array}{l}\text { G1. I have administrative and financial powers but I cannot exercise them. Powers only exist in policy papers, practically we cannot use them. I have } \\
\text { the financial powers of category } 3 \text { officer and I can purchase Computers for my office. But now I am facing the problems of justifying this purchase as } \\
\text { I have an audit objection on this item. Now, in order to settle this objection, I have to spend extra hours and resources-----external auditors raise } \\
\text { baseless issues which is a source of physical and mental stress. (DDO, (M-14) CDGL) }\end{array}$ \\
\hline 8. & Role ambiguity & $\begin{array}{l}\text { H1. Decentralization does not mean overloading one tier with lots of responsibilities. For instance, you have to delegate power in such a way that can } \\
\text { be managed by that organization/tier/individual. For instance, District Coordinating Officer (Bureaucratic head of the CDG) has been assigned } \\
\text { enormous responsibilities. If you want to rationalize the system, powers should be delegated from the DCO down the hierarchy such EDO who are the } \\
\text { departmental heads. Overloading of power results in administrative lapses. Another factor affecting performance is duplication of work. Some of the } \\
\text { powers are being exercised by District Nazim, DCO, and provincial departments which are hindering the proficiency of the lower tier. (EDO, CDGL) }\end{array}$ \\
\hline & Power Plays & $\begin{array}{l}\text { I1. Powers are not devolved in practice. There is violation of power. If we visit schools and find teachers underperforming, we cannot punish them, as } \\
\text { those who are punished will approach their political representatives and then we will start getting pressure from them to do nothing against them. } \\
\text { (DDO (F-1) CDGL) }\end{array}$ \\
\hline
\end{tabular}


Figure 4: A model of managerial enacted discretion in implementing Pakistan education policy reforms

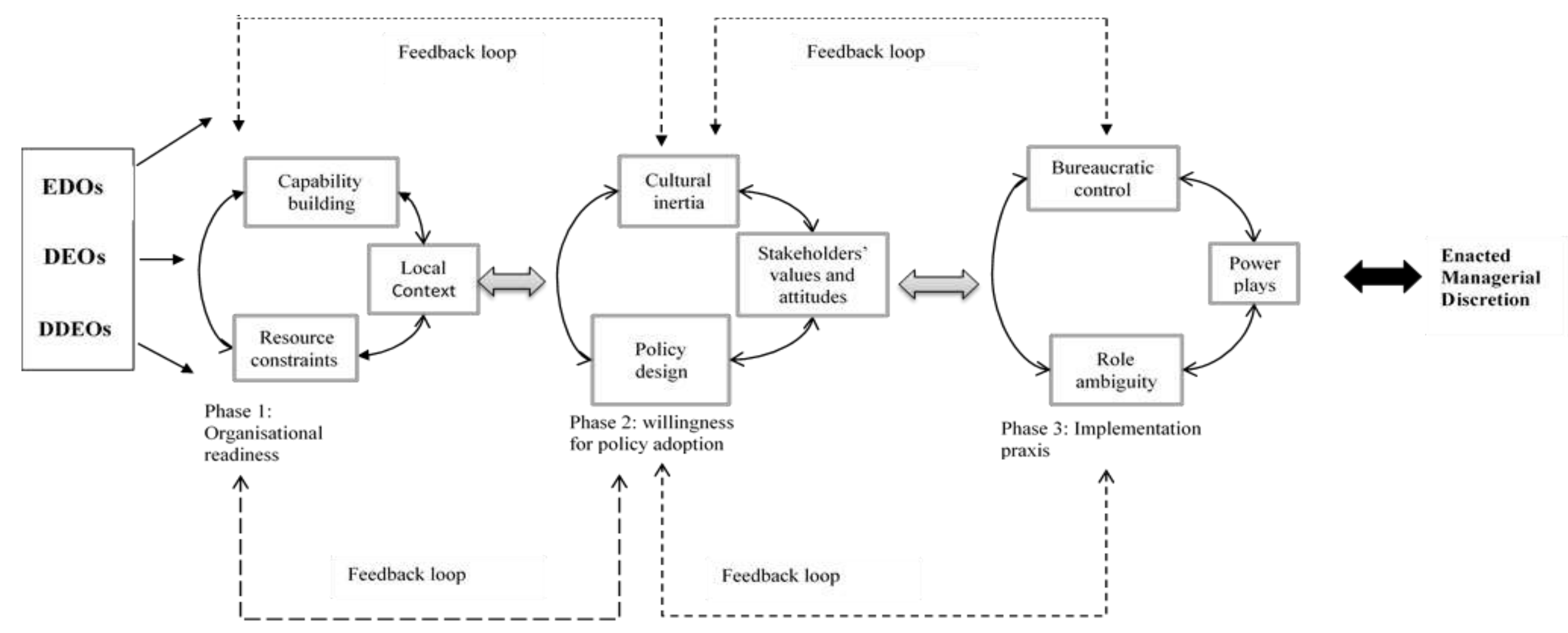

Key education reforms: Devolution of administrative and financial autonomy to education departments; increasing user involvement through SCs and; use of ASS scheme to assist with increased provision of school funding to improve facilities and quality of education for children. 